\title{
POTENSI KANDUNGAN ASETON DARI LIMBAH PUNTUNG ROKOK
}

\author{
Gigih Lintang Prasetyo ${ }^{1}$, Sri Endah Fitriani ${ }^{2}$, Dhimas Pratama Sihotang ${ }^{3}$, Ariany \\ Zulkania $^{4}$ \\ 1,2,3,4Prodi Teknik Kimia, Fakultas Teknologi Industri, Universitas Islam Indonesia \\ Yogyakarta
}

\begin{abstract}
ABSTRAK
Puntung rokok merupakan limbah yang banyak terdapat di lingkungan. Menurut studi laboratorium, dalam rokok terdapat bahan-bahan kimia berbahaya dan logam berat yang dapat mencemari lingkungan. Kandungan kimia pada rokok yang sudah teridentifikasi jumlahnya mencapai 2.500 komponen. Dari jumlah tersebut sekitar 1.100 komponen diturunkan menjadi komponen asap secara langsung dan 1.400 lainnya mengalami dekomposisi atau terpecah, bereaksi dengan komponen lain dan membentuk komponen baru. Sedangkan kandungan kimia dalam asap rokok jumlahnya mencapai 4.800 komponen. Dari berbagai kandungan-kandungan zat yang ada dalam asap rokok yang tidak lolos filter Cambridge, di dalamnya terdapat senyawa aseton sebanyak 100-650 $\mu \mathrm{g}$ per batang rokok yang berpotensi untuk disintesis sehingga dapat menghasilkan suatu produk yang bermanfaat. Penelitian ini bertujuan untuk mengetahui kandungan aseton dalam limbah puntung rokok dengan variabel suhu dan perbandingan katalis dengan tembakau. Limbah puntung rokok diubah menjadi cairan kondesat dengan proses pembakaran menggunakan metode pirolisis. Analisa kandungan aseton dapat diketahui dengan pengujian cairan kondensat menggunakan Gas Chromatoghraphy-Mass Spectrometry. Dengan perbedaan variabel suhu dan perbandingan katalis dengan tembakau akan diperoleh jumlah kandungan aseton yang berbeda. Keterbatasan yang dihadapi oleh peneliti adalah tidak adanya alat untuk menangkap dan menyimpan gas hasil pirolisis yang tidak terkondensasi.
\end{abstract}

Kata kunci: Sintesis, limbah puntung rokok, aseton

\section{PENDAHULUAN}

Indonesia merupakan salah satu negara penghasil tembakau yang cukup besar di dunia. Tembakau yang dihasilkan sebagian besar digunakan untuk produksi rokok. Lebih dari sepertiga penduduk Indonesia (atau $36,3 \%$ ) menjadi konsumen rokok menurut data dari Kementrian Kesehatan. Pada tahun 2013, konsumsi rokok di Indonesia mencapai 302 miliar batang (Lembaga Demografi Universitas Indonesia, 2014). Angka ini menempatkan Indonesia di urutan pertama sebagai negara di Asia Tenggara yang memiliki jumlah perokok tertinggi. Menurut data global sekitar $80 \%$ puntung rokok dibuang sembarangan, atau sekitar 660 juta puntung per hari. Hal ini berarti jumlah limbah puntung rokok yang dihasilkan per tahun jika dikalkulasikan sekitar 151 juta liter, setara dengan volume dari 60 kolam renang ukuran olimpiade. Jumlah tersebut akan terus meningkat dari tahun ke tahun.

Puntung rokok merupakan limbah yang banyak terdapat di lingkungan sehingga dapat mengurangi estetika bahkan merusak keindahan lingkungan. Menurut studi laboratorium, terdapat bahan-bahan kimia seperti arsenik, nikotin, hidrocarbon aromatic polisiklik dan logam berat yang dapat mencemari lingkungan. Sebuah penelitian di Universitas California menemukan bahwa bila sebuah puntung direndam di dalam satu liter air selama empat hari, maka air itu cukup beracun untuk mematikan beberapa spesies hewan. Sementara itu, ketika dibuang ke tanah, racun yang sama juga masuk ke dalam tanah, lalu membuat tanah menjadi beracun bagi hewan dan tumbuhan. 
Limbah puntung rokok memerlukan waktu sampai 10 tahun untuk bisa benar-benar hancur dan membusuk. Utamanya selulosa asetat yang terdapat dalam filter rokok merupakan sejenis plastik yang sulit untuk terurai dan dapat bertahan lama di lingkungan. Filter ini dapat menjadi partikel-partikel yang sangat kecil dalam bentuk microfibers dan microplastics. Dengan adanya permasalahan tersebut, maka diperlukan sebuah upaya untuk mengolah limbah puntung rokok yang dapat mencemari lingkungan. Dari berbagai kandungan zat yang ada dalam rokok, terdapat potensi untuk sintesis aseton yang nantinya dapat dimanfaatkan untuk kepentingan lebih lanjut. Aseton dalam kehidupan seharihari digunakan sebagai pelarut, penghilang cat kuku, dan lain sebagainya. Selain itu penelitian ini juga bertujuan untuk mengetahui kandungan aseton dalam limbah puntung rokok serta mengetahui variabel katalis dan suhu yang efektif yang dapat menghasilkan aseton terbanyak.

\section{TINJAUAN PUSTAKA}

Rokok merupakan produk yang mengandung zat-zat yang bersifat adiktif (menimbulkan kecanduan), dan jika dikonsumsi dapat mengakibatkan bahaya bagi kesehatan individu dan masyarakat. Karena dalam rokok terdapat kurang lebih 4.000 macam zat kimia, antara lain nikotin yang bersifat adiktif dan tar yang bersifat karsinogenik yang dapat mengakibatkan penyakit seperti kanker, penyakit jantung, impotensia, penyakit darah, emfisema, bronkitis kronik, gangguan kehamilan dan janin serta banyak lagi lainnya (Negoro, 2000).

Dalam tembakau rokok lebih dari 3800 senyawa kimia ditemukan, dan kelompok terbesar adalah senyawa nitrogen sebanyak 24\%, serta hidrokarbon sebanyak 15\%. Komponen utamanya adalah karbon monoksida (CO), yaitu $5-23 \mathrm{mg} /$ batang rokok; asam nitrat $\quad 0,1-1,6 \quad \mathrm{mg} /$ batang rokok; asetaldehid 0,2-1,3 $\mathrm{mg} / \mathrm{batang}$ rokok; asam format $0,1-1,1 \mathrm{mg} / \mathrm{batang}$ rokok; metil klorida 0,1-0,8 mg/batang rokok; asam sianida 0,03-0,7 mg/batang rokok, serta 50 macam senyawa karsinogen lainnya. Asap rokok selain dapat membahayakan kesehatan perokok sendiri juga dapat membahayakan lingkungannya, yaitu orang-orang yang berada disekitarnya. Menurut hasil penelitian, asap rokok mengandung senyawa racun organoklorin seperti: metilklorida, metilen-klorida, kloroform, trikloroetilen, tetrakloro-etilen, dan vinil klorida. (Hasanien, E. dkk, 1990). Kandungan kimia dalam asap rokok mencapai 4.800 macam. Diantaranya terdapat kandungan aseton di dalam asap rokok.

Aseton merupakan senyawa karbonil yang memiliki gugus fungsi keton (-CO). Aseton, juga dikenal sebagai propanon, dimetil keton, 2propanon, propan-2-on, dimetilformaldehida, dan $\beta$-ketopropana. Aseton dapat dibuat dari alkohol sekunder dengan cara oksidasi. Aseton adalah senyawa organik yang berupa cairan tidak berwarna dan mudah terbakar. Aseton merupakan senyawa keton yang paling sederhana. Aseton larut dalam berbagai perbandingan air, etanol, dietil eter, dan lain-lain. Aseton sendiri juga merupakan pelarut penting.

Aseton dibuat secara langsung maupun tidak langsung dari propena. Secara umum, melalui proses kumena, benzena dialkilasi dengan propena dan produk proses kumena (isopropilbenzena) dioksidasi untuk menghasilkan fenol dan aseton:

$$
\begin{gathered}
\mathrm{C}_{6} \mathrm{H}_{5} \mathrm{CH}\left(\mathrm{CH}_{3}\right)_{2}+\mathrm{O}_{2} \rightarrow \mathrm{C}_{6} \mathrm{H}_{5} \mathrm{OH}+ \\
\mathrm{OC}\left(\mathrm{CH}_{3}\right)_{2}
\end{gathered}
$$

Konversi di atas terjadi melalui zat antara kumena hidroperoksida, $\mathrm{C}_{6} \mathrm{H}_{5} \mathrm{C}(\mathrm{OOH})\left(\mathrm{CH}_{3}\right)_{2}$. Aseton juga diproduksi melalui propena yang dioksidasi langsung dengan menggunakan katalis $\mathrm{Pd}(\mathrm{II}) / \mathrm{Cu}(\mathrm{II})$, mirip seperti 'proses wacker'. Aseton adalah zat yang tidak berwarna dengan berat jenis $0.812 \mathrm{~g} / \mathrm{mL}$ pada suhu $0^{\circ} \mathrm{C}$. Aseton juga merupakan senyawa yang memiliki bau khas. Aseton juga merupakan suatu pelarut yang baik bagi zat-zat organik. Salah satu ciri-ciri dari cairan aseton ini ialah gampang sekali dalam menguapnya. Ciri-ciri dari aseton lainnya adalah gampang sekali terbakar, dan biasanya dihasilkan tanpa ada warna. Kandungan dari aseton ini mempunyai bau.

Menurut penelitian yang dilakukan oleh Samsuri Tirtosastro (Kandungan Kimia Tembakau dan Rokok, 2009) 
dilakukan pengujian untuk mengetahui kandungan kimia dalam asap rokok dengan menggunakan smoking machine yang dilengkapi dengan filter Cambridge. Metode filer Cambridge merupakan uji yang dilakukan oleh U.S. Federal Trade Commission (FTC) untuk mengetahui kandungan tar dan nikotin dalam rokok yang diproduksi di Amerika Serikat. Uji ini dilakukan untuk memberikan informasi kepada perokok mengenai kandungan tar dan nikotin di berbagai macam merk rokok. Filter Cambridge ini nantinya akan menangkap asap yang dihasilkan saat rokok dihisap dengan menggunakan smoking machine. Asap yang dihisap ini kemudian dinamakan sebagai kondensat. Selain itu juga terdapat asap yang tidak tertangkap oleh filter cambridge. Asap ini berasal

\begin{tabular}{|c|c|c|c|}
\hline Senyawa & $\begin{array}{l}\text { Konsentrasi/Batang } \\
\text { Rokok (\%Aliran Asap } \\
\text { Total) }\end{array}$ & Senyawa & $\begin{array}{l}\text { Konsentrasi/Batang } \\
\text { Rokok (\%Aliran Asap } \\
\text { Total) }\end{array}$ \\
\hline Nitrogen & $280-120 \mathrm{mg}(56-64 \%)$ & Methyl-formate & $20-30 \mu \mathrm{g}$ \\
\hline Oksigen & $50-70 \mathrm{mg}(11-14 \%)$ & Asam volatil lain & $5-10 \mu \mathrm{g}$ \\
\hline $\begin{array}{l}\text { Karbon } \\
\text { dioksida }\end{array}$ & $15-65 \mathrm{mg}(9-13 \%)$ & Formaldehida & $20-100 \mu \mathrm{g}$ \\
\hline $\begin{array}{l}\text { Karbon } \\
\text { monoksida }\end{array}$ & $14-23 \mathrm{mg}(2-5 \%)$ & Asetaldehida & $400-1400 \mu \mathrm{g}$ \\
\hline Air & $7-12 \mathrm{mg}(1,2-2,5 \%)$ & Acrolein & $60-140 \mu g$ \\
\hline Argon & $5 \mathrm{mg}(1 \%)$ & $\begin{array}{l}\text { Aldehida volatil } \\
\text { lain }\end{array}$ & $80-140 \mu \mathrm{g}$ \\
\hline Hidrogen & $0,5-1,0 \mathrm{mg}$ & Aseton & $100-650 \mu \mathrm{g}$ \\
\hline Amonia & $10-130 \mu \mathrm{g}$ & Keton volatil lain & $50-100 \mu \mathrm{g}$ \\
\hline $\begin{array}{l}\text { Nitrogen } \\
\text { oksida Nox }\end{array}$ & $100-680 \mu \mathrm{g}$ & Methanol & $80-100 \mu \mathrm{g}$ \\
\hline $\begin{array}{l}\text { Hidrogen } \\
\text { sianida }\end{array}$ & $400-500 \mu \mathrm{g}$ & $\begin{array}{l}\text { Alkohol volatil } \\
\text { lain }\end{array}$ & $10-30 \mu g$ \\
\hline $\begin{array}{l}\text { Hidrogen } \\
\text { sulfida }\end{array}$ & $20-90 \mu \mathrm{g}$ & Acetonitrile & $100-150 \mu \mathrm{g}$ \\
\hline Metana & $1,0-2,0 \mathrm{mg}$ & $\begin{array}{l}\text { Volatile Nitriles } \\
\text { lain }\end{array}$ & $50-80 \mu \mathrm{g}$ \\
\hline Volatile alkene & $0,4-0,5 \mathrm{mg}$ & Furan & $20-40 \mu \mathrm{g}$ \\
\hline $\begin{array}{l}\text { Volatile } \\
\text { alkenes lain }\end{array}$ & $1,0-1,6 \mathrm{mg}$ & $\begin{array}{l}\text { Volatile Furanes } \\
\text { lain }\end{array}$ & $45-125 \mu \mathrm{g}$ \\
\hline Isoprene & $0,2-0,4 \mathrm{mg}$ & Pyridine & $20-200 \mu \mathrm{g}$ \\
\hline Butadiena & $25-40 \mu \mathrm{g}$ & Picolines & $15-80 \mu \mathrm{g}$ \\
\hline Asetilena & $20-35 \mu \mathrm{g}$ & 3-Vinylpyridine & $7-30 \mu \mathrm{g}$ \\
\hline Benzena & $6-70 \mu \mathrm{g}$ & $\begin{array}{l}\text { Volatile } \\
\text { Pyridines lain }\end{array}$ & $20-60 \mu \mathrm{g}$ \\
\hline Toluena & $5-90 \mu \mathrm{g}$ & Pyrrole & $0,1-10 \mu \mathrm{g}$ \\
\hline Syrene & $10 \mu \mathrm{g}$ & Pyrrolidine & $10-18 \mu \mathrm{g}$ \\
\hline $\begin{array}{l}\text { Hidrokarbon } \\
\text { aromatik lain }\end{array}$ & $15-35 \mu \mathrm{g}$ & $\begin{array}{l}\text { N-Methyl } \\
\text { pyrrolidine }\end{array}$ & $2,0-3,0 \mu \mathrm{g}$ \\
\hline Asam format & $200-600 \mu \mathrm{g}$ & $\begin{array}{l}\text { Volatile } \\
\text { Pyrazines }\end{array}$ & $3,0-8,0 \mu \mathrm{g}$ \\
\hline Asam asetat & $300-1700 \mu \mathrm{g}$ & Metil amina & $4-10 \mu \mathrm{g}$ \\
\hline Asam & $100-300 \mu \mathrm{g}$ & Amines aliphatic & $3-10 \mu \mathrm{g}$ \\
\hline
\end{tabular}

dari rokok yang dihisap oleh smoking machine dan asap yang keluar saat rokok tidak dihisap atau asap samping (sidestream).

Hasil analisis komponen kimia utama asap yang lolos filter Cambridge terkandung jumlah aseton sebanyak 100-650 $\mu \mathrm{g}$. Sesuai dengan tabel xx di bawah ini. Kandungan tersebut cukup besar untuk konsentrasi setiap satu batang rokok. Pada saat ini aseton banyak digunakan untuk pelarut, di samping untuk bahan baku dalam pembuatan senyawa kimia petroleum seperti metal isobutil keton (MIBK, metal meta akrilat, metal isobutil karbinol, bisfenol A, dan lain-lain). Konsumen bahan kimia ini adalah industri cat, pernis, karet, acetic acid, plastik, dan kosmetik. 
Distilasi kering disebut juga sebagai pirolisis. Selain itu, pirolisis sering disebut juga sebagai termolisis. Secara definisi, pirolisis adalah proses terhadap suatu materi dengan menambahkan aksi temperature yang tinggi tanpa kehadiran udara (khususnya oksigen). Untuk menghilangkan kandungan oksigen di dalam reaktor termal dapat dilakukan dengan injeksi nitrogen atau dengan menggunakan isolasi yang baik sehingga tidak ada kandungan oksigen di dalam reaktor termal. Dalam proses pirolisis ini ada tiga produk dalam prosesnya yaitu: gas, pirolisis oil, dan arang, besarnya produk yang akan dihasilkan dipengaruhi oleh kondisi proses terutama temperatur dan laju pemansan. Perbedaan utama proses pirolisis dengan gasifikasi dan insenerasi adalah dalam hal jumlah oksigen yang di-supply ke reaktor termal. Proses pirolisis sangat banyak digunakan di industri kimia, misalnya untuk menghasilkan arang, karbon aktif, metanol, dan bahan kimia lainnya dari kayu, untuk mengkonversi diklorida etilena menjadi vinil klorida untuk membuat PVC, untuk memproduksi kokas dari batubara, untuk mengkonversi biomassa menjadi syngas, untuk mengubah sampah menjadi zat yang aman untuk dibuang, dan untuk mengubah hidrokarbon menengah berat dari minyak menjadi lebih ringan, seperti bensin (Widjaya, 1982).

Suhu perokokan atau proses distilasi kering (pirolisis) mencapai $884^{\circ} \mathrm{C}$ saat diisap dan turun menjadi $835^{\circ} \mathrm{C}$ atau kurang jika lama tidak diisap (Geiss dan Kotzias, 2007). Kesempurnaan pembakaran, terutama tingginya suhu, akan mempengaruhi produksi komponen kimia asap, sehingga komponen kimia yang dihasilkan juga beragam.

\section{METODE PENELITIAN}

Limbah puntung rokok yang akan digunakan dalam penelitian ini diambil di sekitar lingkungan kampus Fakultas Teknologi Industri Universitas Islam Indonesia diantaranya di kantin fakultas dan kantin pusat. Metode yang digunakan untuk mengumpulkan puntung rokok adalah dengan
(Tirtosastro, 2009)

menyiapkan tempat sampah khusus untuk puntung rokok pada beberapa titik yang strategis di tempat-tempat tersebut. Selanjutnya limbah puntung rokok tersebut akan diambil per hari selama dua minggu.

\section{Persiapan Bahan Baku}

Limbah puntung rokok yang telah terkumpul satu persatu dipisahkan dari filternya, sehingga yang digunakan pada penelitian hanya bagian tembakaunya saja. Bahan yang diambil dari puntung rokok hanya bagian tembakaunya saja karena filter yang ada dalam rokok merupakan senyawa non-biomassa (terdapat kandungan selulosa) sehingga nantinya akan menghambat proses berikutnya yakni proses pirolisis. Bahan yang digunakan untuk penelitian ini merupakan suatu biomassa sedangkan bagian filter rokok bukan merupakan biomassa. Kemudian tembakau yang telah dipisahkan dioven selama 2 jam pada suhu $60^{\circ} \mathrm{C}$ untuk menghilangkan kadar air pada bahan tersebut. Lalu dibuat menjadi ukuran yang lebih kecil dengan menggunakan grinder.

\section{Aktivasi Katalis}

Penggunaan katalis dalam proses pirolisis adalah untuk mempercepat proses pirolisis dan sekaligus menurunkan suhu operasi. Katalis yang digunakan pada penelitian ini yaitu arang yang diaktivasi. Arang digunakan sebagai katalis karena mudah diperoleh dan memiliki harga yang ekonomis. Sebelum digunakan, arang ditumbuk terlebih dahulu, kemudian arang yang telah dihaluskan di-screening untuk memperoleh ukuran 100 mesh. Selanjutnya arang dengan ukuran 100 mesh dioven selama 1 jam dengan suhu $100^{\circ} \mathrm{C}$ untuk menghilangkan kadar air pada arang tersebut. Proses aktivasi katalis dilakukan dengan menggunakan larutan $\mathrm{HCl} 0,1 \mathrm{M}$. Penggunaan larutan $\mathrm{HCl}$ untuk aktivasi katalis ini karena larutan $\mathrm{HCl}$ memiliki daya aktivasi cukup kuat dibanding dengan larutan lain. Arang yang telah dikeluarkan dari oven direndam pada larutan $\mathrm{HCl} 0,1 \mathrm{M}$ selama 24 jam. Setelah diaktivasi dengan menggunakan larutan $\mathrm{HCl}$ kemudian arang dicuci dengan menggunakan aquadest. Pencucian dengan aquadest dilakukan dengan tujuan untuk 
menetralkan $\mathrm{pH}$ asam yang terjadi selama proses aktivasi. Pencucian dengan aquadest dilakukan secara berulang hingga memperoleh hasil $\mathrm{pH}$ yang netral. Kemudian arang disaring dengan menggunakan kertas saring dan dioven kembali guna menghilangkan kadar air dalam arang tersebut.

\section{Proses Pirolisis}

Proses pirolisis dilakukan dengan memasukkan bahan baku ditambah dengan katalis yang sebelumnya telah diaktivasi. Jumlah bahan dalam reaktor termal terdiri dari perbandingan tembakau:arang tertentu, yaitu tanpa katalis, $1: 1 / 10$, dan $1: 1 / 20$. Adapun proses pirolisis tanpa penambahan katalis sebagai perbandingan terhadap reaksi yang menggunakan katalis. Reaksi ini berlangsung pada reaktor pirolisator yang bekerja dengan variabel suhu $800^{\circ} \mathrm{C} ; 850^{\circ} \mathrm{C}$; dan $900^{\circ} \mathrm{C}$. Proses pirolisis dilakukan tanpa menggunakan oksigen. Untuk menghilangkan oksigen di dalam reaktor termal diinjeksikan nitrogen ke dalam reaktor termal. Asap hasil pembakaran dilewatkan ke dalam 2 tabung paralel yang berisi es batu untuk dikondensasi. Kemudian cairan kondensat diambil dan dianalisa.

\section{Analisa GCMS (Gas Chromatography} - Mass Spectrometry)

Persiapan sampel yang akan diuji yaitu cairan kondensat diubah terlebih dahulu menjadi fasa uap. Kemudian proses derivatisasi sampel yang akan diuji. Sampel uji diinjeksikan ke kolom GC yang melewati heated injection port. Campuran dibawa gas pembawa dengan laju alir tertentu melewati kolom GC yang dipanaskan dalam pemanas. Kolom GC memiliki cairan pelapis (fasa diam) yang inert. Pendeteksian berlangsung di dalam spektroskopi massa dengan mekanisme penembakan senyawa oleh elektron menjadi molekul terionisasi dan pencatatan pola fragmentasi yang terbentuk dibandingkan dengan pola fragmentasi senyawa standard yang diindikasikan dengan prosentase Similarity Index (SI). Kemudian spektra massa dicatat secara reguler dalam interval 0,5-1 detik selama pemisahan GC dan disimpan dalam sistem instrumen data untuk digunakan dalam analisis. Spektra massa berupa fingerprint ini dapat dibandingkan dengan acuan.

\section{KETERBATASAN}

Keterbatasan yang dihadapi dalam penelitian ini adalah karena tidak adanya alat untuk menangkap dan menyimpan gas hasil pirolisis yang tidak terkondensasi. Dimungkinkan gas hasil pirolisis yang tidak terkondensasi mengandung aseton dalam jumlah yang lebih besar dibandingkan dengan cairan yang sudah terkondensasi.

\section{KESIMPULAN}

Limbah puntung rokok yang selama ini banyak terdapat di lingkungan memiliki potensi untuk dimanfaatkan lebih lanjut. Pemanfaatan tersebut dapat dilakukan dengan sintesa aseton yang terdapat dalam limbah puntung rokok tersebut. Penelitian kadar aseton pada limbah puntung rokok dilakukan dengan cara pirolisis yang terkondensasi menjadi cairan yang dapat dianalisa dengan GCMS (Gas Chromatography - Mass Spectrometry).

\section{DAFTAR PUSTAKA}

Drastinawati, and Rozanna Sri Irianty. 2013. "Pemanfaatan Ekstrak Nikotin Limbah Puntung Rokok sebagai Inhibitor." Jurnal Teknobiologi Universitas Riau.

Kusuma, Dani Ali, Sudarminto S. Yuwono, and Siti Narsito Wulan. 2004. "Studi Kadar Nikotin dan Tar Sembilan Merk Rokok Kretek Filter." Jurnal Teknologi Pertanian Universitas Brawijaya.

Palupi, Retno. 2009. Prarancangan Pabrik Aseton Proses Dehidrogenasi Isopropil Alkohol Kapasitas 21.000 ton/tahun. Surakarta: Jurusan Teknik Kimia Universitas Muhammadiyah Surakarta.

Sediawan, WB. 2014. "BAB II. Tinjauan Pustaka." Publikasi IImiah UMS. https://publikasiilmiah.ums.ac.id/ bitstream/handle/11617/5542/B AB\%20II\%20TINJAUAN\%20PU STAKA_pdf?sequence $=3 \&$ isAll owed $=y$.

Tirtosastro, Samsuri, and A. S. Murdiyati. 2010. "Kandungan Kimia Tembakau dan Rokok." Buletin Tanaman Tembakau, Serat \& Minyak Industri.

Tri Kurnia Dewi, Arif Nurrahman, Edwin Permana. 2009. "Pembuatan 
Karbon Aktif dari Kulit Ubi Kayu (Mannihot esculenta)." Jurnal Teknik Kimia, No. 1, Vol. 16.

http://kompak.co/blog/penggerak/byjalal/menyelamatkan-bumi-daridampak-produksi-dan-

konsumsi-rokok/ (Diunduh pada tanggal 3 November 2017 pukul 23.30 WIB)

https://www.academia.edu/32356718/SI

NTESIS_ASETON (Diunduh

pada tanggal 3 November 2017

pukul

23.50

WIB) 